\title{
JESZCZE O POPULARYZACJI NAUKI O JEZZYKU DAWNIEJ I DZIŚ
}

\author{
Mariusz Koper \\ Katolicki Uniwersytet Lubelski Jana Pawła II \\ ORCID: 0000-0002-9878-0820
}

\begin{abstract}
Streszczenie. W artykule autor przedstawia najważniejsze zagadnienia dotyczące popularyzacji nauki o języku. Poza zdefiniowaniem terminu popularyzacja wymienia podstawowe wyznaczniki dobrego popularyzowania, omawia historię oraz współczesność popularyzacji nauki o języku polskim. Ponadto charakteryzuje najnowsze formy upowszechniania nauki, uwzględniające zróżnicowane bogactwo świata mediów. W ostatniej części artykułu w ogólnym zarysie autor przedstawia dokonania popularyzatorskie prof. dr. hab. Feliksa Czyżewskiego.
\end{abstract}

Słowa klucze: popularyzacja, język polski, nauka, językoznawstwo, językoznawca, wiedza, niespecjalista, kultura języka

\section{WPROWADZENIE}

Tak sformułowany tytuł niniejszego artykułu z leksemem inicjalnym jeszcze bezpośrednio koresponduje z referatem prof. dr. hab. Bogdana Walczaka pt. Popularyzacja wiedzy językoznawczej dawniej $i$ dziś, który został wygłoszony przez tegoż badacza na jubileuszowej konferencji Instytutu Języka Polskiego PAN, zatytułowanej „Przyszłość językoznawstwa - językoznawstwo przyszłości" (Przegorzały, 11-12 czerwca 2013 roku). Z założenia więc publikacja niniejsza będzie nawiązywała do refleksji wyartykułowanych przez tego znamienitego badacza języka, ale również wytrawnego i doświadczonego popularyzatora wiedzy na ten temat. Z uwagi na fakt, że B. Walczak zasadniczo skupia się na popularyzacji języka, jaka miała miejsce przed II wojną światową, artykuł ten można również po części traktować jako uzupełnienie oraz znaczne poszerzenie przedstawionego w tytule zagadnienia - szczególnie w odniesieniu do czasów współczesnych.

Złożona problematyka, jaką jest niewątpliwie popularyzacja, wymaga na wstępie odpowiedzi na szereg kwestii, tak o charakterze ogólnym, jak 
i szczegółowym. Pytania, jakie się nasuwają, dotyczą zarówno tego, czym jest popularyzacja nauki o języku, jakie są podstawowe wyznaczniki dobrego popularyzowania w ogóle, kto może zostać dobrym popularyzatorem, kto zaś powinien zaniechać tej działalności, jaka problematyka lingwistyczna jest dobra i społecznie użyteczna do popularyzowania, jak wygląda przeszłość i teraźniejszość popularyzacji wiedzy językoznawczej z uwzględnieniem różnych (dawnych oraz nowszych) form przekazu, jak przedstawia się obecnie kondycja popularyzowania wiedzy o języku polskim oraz wreszcie, czy jest ona w ogóle możliwa, zasadna i potrzebna w dzisiejszym wysoce wyspecjalizowanym świecie badań naukowych. Ten szereg pytań skłania autora niniejszego szkicu do dyskursu, w którym pewne kwestie zostaną omówione szerzej, inne zaś jedynie będą zasygnalizowane. $Z$ powodu wieloaspektowości tematyki ukazanej w tej publikacji autor nie rości sobie zatem pretensji do pełnego omówienia wszystkich zagadnień oraz przedstawienia ostatecznych na ich temat wniosków. Intencją autora jest przede wszystkim zwrócenie uwagi na historyczne oraz współczesne trendy w zakresie popularyzowania z przywołaniem szczegółowych egzemplifikacji, które w przyszłości mogą zostać uzupełnione, skorygowane oraz skonfrontowane po uwzględnieniu szerszego materiału i bogactwa zjawisk występujących we współczesnej nauce lub, mówiąc nieco dosadniej, polityce naukowej ${ }^{1}$.

Klasyczna popularyzacja nauki to najogólniej przedstawienie, pokazanie, ale też i dyskusja na temat wiedzy o zjawiskach i procesach badanych w sposób naukowy ${ }^{2}$. W sferze epistemologii i komunikacji nie mniej ważne jest uwzględnienie poziomu dyskursu oraz specyfiki podejmowanej problematyki, która będzie odpowiadała zarówno zapotrzebowaniu odbiorców, jak i ich kompetencji ${ }^{3}$. Uwzględnienie tych wszystkich aspektów sprawia, że popularyzowanie nauki to zadanie specyficzne i niełatwe. Powinni je uprawiać ci, którzy to umieją oraz mają wewnętrzną potrzebę dzielenia się wiedzą ${ }^{4}$. Biorąc pod uwagę tworzywo pisane, należy uznać, że dobry tekst popularnonaukowy to taki, który nie jest zbyt trudny, referuje ciekawe rzeczy wzbudzające zainteresowanie czytelnika, nie opowiada o rzeczach oczywistych, nie zawiera błędów merytorycznych, zbyt dużej liczby słownictwa specjalistycznego i terminów technicznych, nie prezentuje własnych hipotez,

O współczesnych trendach występujących w polskiej polityce naukowej zob. W. Włoskowicz, Nowomowa pseudometanaukowa? O języku polskiej polityki naukowej, „Poradnik Językowy" 2019, nr 10, s. 35-47.

Więcej informacji na temat znaczenia rzeczownika popularyzacja oraz słów pokrewnych zob. R. Pawelec, Popularyzacja, upowszechnianie, czynienie wiadomym wszem wobec, „Studia Medioznawcze" 2017, nr 3, s. 13-19.

M. Fikus, O upowszechnianiu nauki w Polsce na progu 2016, „Nauka” 2016, nr 1, s. 181. 4 Ibidem. 
niepotwierdzonych przez badania naukowe $\mathrm{e}^{5}$. Bardzo ważne są też retoryczne aspekty popularyzacji naukowej. Dobrze oddaje to sentencja Stanisława Jerzego Leca - „Nie wystarczy mówić do rzeczy. Trzeba mówić do ludzi”. Uwzględnienie tych wszystkich warunków prowadzi do konstatacji, że nie każdy naukowiec może być dobrym popularyzatorem, a tym bardziej nie każdy niespecjalista powinien uprawiać tę społecznie użyteczną dyscyplinę. Ten pierwszy może dysponować bowiem ogromną wiedzą, której jednak nie jest w stanie przełożyć na język przeznaczony „dla wszystkich”, ten drugi zaś winien dysponować nie tylko umiejętnością przystępnego mówienia i pisania o rzeczach trudnych, ale też, jak pisze Magdalena Fikus, dobrze jest, „gdy popularyzujący zetknął się z nauką. Wtedy ma do niej oraz do samego procesu upowszechniania większy szacunek" . Należy zatem zgodzić się $\mathrm{z}$ postulatem $\mathrm{B}$. Walczaka, który uważa, że to na naukowcach, w tej zaś konkretnej sytuacji na polskich językoznawcach spoczywa główne zadanie popularyzowania, gdyż nikt ich w tej materii nie zastąpi i nie zrobi tego lepiej, bo przy szerokim uwzględnieniu różnorakich kompetencji lingwistycznych oraz nierzadko złożonej metodologii.

\section{POPULARYZACJA NAUKI O JĘZYKU DAWNIEJ}

Wydaje się, że nieklasyczne pojęcie popularyzacji nauki o języku sięga początków polskiego językoznawstwa naukowego. Potwierdzają to w dużej mierze ustalenia B. Walczaka, który w przywołanym we wstępie do tego artykułu referacie dokonuje przeglądu dwunastu początkowych wydań czasopisma „Język Polski” z lat 1913-1927. Jak zauważa, ze względu na język, terminologię oraz tok wykładu w poszczególnych numerach tegoż czasopisma dominują artykuły, notki i recenzje stricte naukowe, które z powodu ukształtowania językowo-stylistycznego oraz reżimu terminologicznego są zasadniczo niedostępne dla niespecjalistów. W poszczególnych numerach tego periodyku znajdują się jednak i takie teksty, które nie są czystą i klasyczną popularyzacją w tym sensie, że nie udostępniają czegoś, co w naukowej wersji zostało już zaprezentowane, ale z uwagi na przystępny język, terminologię, doniosłość społeczną oraz atrakcyjność tematyki można je również zaliczyć do publikacji popularyzatorskich, dostępnych dla szerszego ogółu czytelników, nietracących jednocześnie niczego ze swojej rangi naukowej.

\footnotetext{
$5 \quad$ K. Jarosz, Komercjalizacja nauki i mechanizmy podnoszenia atrakcyjności artykułów popularnonaukowych, „Zeszyty Prasoznawcze” 2011, t. 54, nr 3-4, s. 71.

6 Za: M. Załęska, Retoryczne aspekty popularyzacji naukowej, „Acta Universitatis Lodziensis. Folia Litteraria Polonica” 2016, 1, s. 59.

7 M. Fikus, op. cit., s. 181.
} 
Ich walor naukowo-badawczy wynika z faktu, że czas, w którym powstawały, to początkowy okres rozwoju dyscypliny, jaką jest językoznawstwo. Niewiele było wówczas rzeczy definitywnie naukowo opracowanych. Jak słusznie zauważa B. Walczak, nie jest to więc klasyczne popularyzowanie wiedzy językoznawczej. Jak się wydaje autorowi niniejszego artykułu, procesowi upowszechniania nauki paradoksalnie mógł sprzyjać wówczas początkowy etap językoznawstwa naukowego w ogóle, które determinowało cechy idiolektu samych autorów z dosyć przystępną jak na owe czasy terminologią specjalistyczną włącznie.

W dalszej części swojego referatu B. Walczak charakteryzuje problematykę, którą zajmowali się ówcześnie badacze nauki o języku. Nurt naukowy a zarazem popularyzatorski uprawiali wówczas najwybitniejsi przedstawiciele polskiego językoznawstwa. Byli nimi m.in.: Jan Baudouin de Courtenay, Tytus Benni, Jan Stanisław Bystroń, Witold Doroszewski, Tadeusz Lehr-Spławiński, Jan Łoś, Kazimierz Nitsch, Jan Michał Rozwadowski, Mikołaj Rudnicki, Witold Taszycki, Henryk Ułaszyn. Pisali o rzeczach doniosłych i aktualnych w sensie społecznym, podejmując m.in. kwestię różnic między granicami językowymi, narodowymi i państwowymi, granic języka polskiego w relacji do granic państwowych, sprawę zróżnicowania regionalnego polszczyzny, problematykę języka międzynarodowego itp. Drugi obszar, którym się zajmowali, stanowiły publikacje atrakcyjne i do dziś budzące żywe zainteresowanie, a wyjaśniające złożone, nierzadko bardzo trudne kwestie, w sposób możliwie najbardziej przystępny. Dominowała tutaj problematyka etymologiczna, związana zarówno z wyrazami pospolitymi, jak i z nazwami własnymi. Wśród wielu artykułów i notek na ten temat B. Walczak przywołuje m.in. zagadnienia związane z nazwami pokrewieństwa i powinowactwa w dziejach polszczyzny, artykuły o nazwach własnych Kopernik, Magura, Spisz czy Tatry itp. Nie brakowało też publikacji podejmujących kwestię etykiety językowej, języka jako zwierciadła kultury, przebiegu zmian językowych oraz związanego z nimi stopnia rozwoju cywilizacji i charakterystyki narodu itp. Wśród wielu publikacji i autorów B. Walczak wymienia również kilkuodcinkową serię artykułów J. Rozwadowskiego $O$ zjawiskach $i$ rozwoju języka $a^{8}$ który nazywa arcywzorem popularyzacji, zaś autora cyklu określa mianem osoby mającej wielki dar przystępnego przedstawiania rzeczy złożonych i trudnych. Podsumowując tę część swojego referatu, B. Walczak stwierdza, że był to złoty wiek popularyzacji wiedzy językoznawczej. Analizując doniosłość społeczną charakteryzowanych przez autora publikacji, ich atrakcyjność, wysoki poziom oraz przystępny wywód naukowy, nie sposób nie zgodzić się z tak postawioną tezą.

\footnotetext{
8 Jest to cykl artykułów drukowanych na łamach „Języka Polskiego” w latach 1913-1921, wydanych następnie osobno w 1921 roku oraz po raz drugi w 1950.
} 
W okresie powojennym (do lat 70. XX wieku) - kontynuuje B. Walczak - wydawano wiele publikacji popularyzujących wiedzę o języku polskim. Poznański językoznawca zauważa jednak, że sukcesywnie zmniejszała się liczba popularyzatorów wśród lingwistów zasłużonych na niwie stricte naukowej. Coraz rzadziej - zaznacza - wydawane były udane popularyzatorskie książki typu Mówia nazwy, autorstwa zasłużonego na niwie naukowej badacza Stanisława Rosponda9. Pojawili się za to doskonali popularyzatorzy, którzy na polu naukowym nie pozostawili już tak imponującego dorobku. B. Walczak zalicza do nich Stefana Reczka oraz Witolda Cienkowskiego ${ }^{10}$. Zdaniem B. Walczaka jedną z ostatnich publikacji powojennych, która odwołuje się swoimi tradycjami do starych, ale sprawdzonych wzorców popularyzowania, jest książka Anny Wierzbickiej pt. O języku dla wszystkich ${ }^{11}$. Już sam tytuł - konkluduje poznański językoznawca - informuje, że publikacja adresowana jest nie tylko dla specjalistów. Poza wymiarem popularyzatorskim można w niej odnaleźć istotne walory naukowe.

Ważne, a nieuwzględnione przez B. Walczaka (autor ten skupia się głównie na popularyzacji wiedzy językoznawczej udostępnianej w formie publikacji książkowych, artykułów, przyczynków, notek itp.), wydaje się nieco inne upowszechnianie wiedzy o języku polskim, zainicjowane jeszcze przed II wojną światową przez wybitnego polskiego językoznawcę Witolda Doroszewskiego. W odróżnieniu od wcześniejszych odnotowanych metod popularyzowania lingwista ten poza upowszechnianiem języka polskiego w formie pisanej jako jeden z pierwszych występował $\mathrm{z}$ ważnymi zagadnieniami językowymi na łamach środków masowego przekazu. W. Doroszewski uchodzi za pomysłodawcę poradnictwa językowego w rozgłośni radiowej. Jeszcze przed wojną, bo w 1935 roku zaczął prowadzić audycję „Radiowa skrzynka językowa”, którą po 1948 roku przekształcił w „Radiowy poradnik językowy”. Przez czterdzieści lat odpowiadał na pytania słuchaczy. W swoich programach uzmysławiał radiosłuchaczom, jak ważna jest troska o język ojczysty oraz poznawanie i rozumienie tego, co się w nim dzieje. Należy w tym miejscu podkreślić, iż jest to pierwsze tak śmiałe wprowadzenie nowego kanału komunikowania i popularyzowania, jakim jest rozgłośnia radiowa. Idea ta będzie kultywowana w czasach współczesnych przez kontynuatorów myśli W. Doroszewskiego.

\footnotetext{
$9 \quad$ S. Rospond, Mówiq nazwy, Warszawa 1976.
}

10 Zarówno jeden, jak i drugi językoznawca to autorzy szeregu publikacji popularyzatorskich, zob. m.in. S. Reczek, W rzecz polska wstapić, Wrocław 1988; idem, Stowo się rzekło, czyli monolog o kulturze języka, Warszawa 1988; W. Cienkowski, Kalejdoskop językowy, Warszawa 1967; idem, Język dla wszystkich, Warszawa 1980, idem, Tajemnice imion własnych, Kraków 1992.

$11 \quad$ A. Wierzbicka, O języku dla wszystkich, Warszawa 1967. 


\section{POPULARYZACJA NAUKI O JĘZYKU DZIŚ}

Słuszne spostrzeżenia B. Walczaka w zakresie popularyzacji wiedzy o języku polskim można rozwinąć w odniesieniu tak do historii, jak i do czasów współczesnych. Niełatwo postawić cezurę między popularyzacją dawną a obecną. Zarówno wszelkie periodyzacje, jak i oceny samych zmian zachodzących w języku charakteryzują się na ogół pewnym okresem przejściowym. Można jednak sądzić, że dobrym czasem na wydzielenie odpowiedniej cezury są w tym przypadku przemiany polityczne i ustrojowe po 1989 roku. Z perspektywy nieco ponad 30 lat można stwierdzić, że na zmiany, jakie zaszły na płaszczyźnie popularyzacji wiedzy o języku polskim, istotny wpływ miał nieco odmienny niż dotychczas sposób patrzenia na język - ekspansja jego potoczności, będąca bezpośrednią reakcją na nowomowę, tj. język aparatu władzy, wszechobecna w mediach demokratyzacja języka (szczególnie w przestrzeni internetowej), rozchwianie normy językowej oraz likwidacja cenzury $^{12}$. Ponadto pojawiły się nowe metody popularyzacji nauki, wykorzystujące intensywny rozwój środków masowego przekazu z przestrzenią internetową włącznie ${ }^{13}$. Dały one dodatkowe możliwości rozwoju różnych form popularyzatorskich. Są to m.in. prowadzone na stronach internetowych blogi językowe, poradnie językowe, różnorakie kampanie w mediach społecznościowych, mające na celu popularyzację oraz ochronę języka polskiego. Jedną z najpopularniejszych jest kampania społeczno-edukacyjna pt. „Ojczysty - dodaj do ulubionych”. Jej organizatorami są Rada Języka Polskiego oraz Narodowe Centrum Kultury. Dobrym momentem na refleksję nad stanem polszczyzny jest też Międzynarodowy Dzień Języka Ojczystego - coroczne święto obchodzone 21 lutego, które zostało ustanowione przez UNESCO 17 listopada 1999 roku. Nie mniej ważne są konkursy ortograficzne, oratorskie, dorocznie organizowane przeglądy na Mistrza Mowy Polskiej, plebiscyty, konkursy na słowo roku itp. Jak widać z przedstawionego zarysu, znacznie poszerzają się kanały popularyzowania. Ponadto coraz częściej, chociaż z różnym skutkiem, popularyzacją wiedzy językoznawczej zajmują się niespecjaliści.

W zakresie popularyzacji powojennej, którą B. Walczak przedstawia w ogólnym zarysie, poza odnotowanymi przez językoznawcę inicjatywami popularyzatorskimi oraz publikacjami m.in. Anny Wierzbickiej, Stanisława Rosponda, Stefana Reczka, Witolda Cienkowskiego, po 1989 roku pojawiają

\footnotetext{
12 K. Ożóg, Polszczyzna przełomu XX i XXI wieku. Wybrane zagadnienia, Rzeszów 2011, s. $18-76$.

13 Zob. m.in. artykuł o popularyzacji języka polskiego w mediach publicznych. M. Grzelka, A. Kula, Media publiczne w Polsce a popularyzacja wiedzy o języku polskim, „Poznańskie Studia Polonistyczne. Seria Językoznawcza" 2012, t. 19, z. 2, s. 9-19.
} 
się nowe autorskie propozycje, m.in. Mariana Kucały ${ }^{14}$, Marii Malec ${ }^{15}$ czy też Andrzeja Sieradzkiego ${ }^{16}$. Dotyczą one najczęściej zagadnień dialektologicznych oraz onomastycznych. Wydaje się, że ostatnia z wymienionych dyscyplin językoznawczych zbiera swoje wyjątkowe żniwo w publikacjach popularyzatorskich. Podyktowane jest to zarówno atrakcyjnością problematyki (ciekawa, chociaż nierzadko trudna analiza etymologiczna nazw własnych), jak i konkretnymi potrzebami członków społeczeństwa, którzy od dawna interesowali się pochodzeniem zarówno swoich imion, nazwisk, jak i nazw geograficznych. Świadczy o tym etymologia ludowa, będąca często tworzywem różnych legend o powstaniu miejscowości. Nie mniejszym zainteresowaniem cieszą się gwara i język regionu. Ilustrują to coraz częściej wydawane lokalne słowniczki gwarowe. Ponadto należy odnotować, iż po 1989 roku ukazuje się coraz więcej publikacji z zakresu poradnictwa językowego. Dotyczą one kwestii ogólnych ze wszystkich poziomów języka - od fonologii aż po składnię.

Jak już wspomniano wyżej, kultywowane jest poradnictwo radiowe, zapoczątkowane przez W. Doroszewskiego. Myśl ta przyświeca bowiem późniejszym kontynuatorom dzieła profesora, którzy zajmowali się bądź zajmują do dziś popularyzacją wiedzy o języku polskim, dbałością o system gramatyczny, leksykalny i składniowy oraz funkcjonalność tych wszystkich środków. Spośród szerokiego grona językoznawców medialnych można wymienić tutaj takich badaczy, jak: Walery Pisarek, Andrzej Markowski, Zbigniew Bralczyk czy też ostatnio Katarzyna Mosiołek-Kłosińska. W audycjach radiowych, zajmując się popularyzacją wiedzy o języku, wyjaśniają wszelkie wątpliwości na antenie, doradzają, odpowiadają na pytania oraz omawiają zgłaszane przez słuchaczy nowe, ważne, niepokojące, a czasem także zabawne zjawiska występujące we współczesnej polszczyźnie. Spośród wielu audycji cieszących się zainteresowaniem miłośników języka ojczystego, a poświęconych kulturze słowa mówionego i pisanego (rzadziej zagadnieniom z zakresu etymologii, historii języka) można wymienić ukazujące się w różnych okresach po 1989 roku programy cykliczne typu „Poradnik językowy”, „100 sekund polszczyzny”, „Dwa słowa o języku”, „Co w mowie piszczy”, „Słowoteka”, „Porozmawiajmy o słowach”, „Nasz język współczesny”. Nierzadko na bazie swoich przemyśleń oraz popularyzatorskich programów niektórzy z badaczy publikują następnie książki przeznaczone dla miłośników języka polskiego pragnących zgłębić swoją wiedzę poprzez kontakt ze słowem pisanym ${ }^{17}$.

14 M. Kucała, Twoja mowa cię zdradza: regionalizmy i dialektyzmy języka polskiego, Kraków 1992.

15 M. Malec, O imionach i nazwiskach w Polsce. Tradycja i wspótczesność, Kraków 1996; eadem, Stownik etymologiczny nazw geograficznych Polski, Warszawa 2002.

16 A. Sieradzki, Znaczenie imion, Warszawa 2003.

17 Jedną z pierwszych takich publikacji, wydanych pod 1989 roku, jest książka poradnik pt. Polszczyzna płata nam figle. Poradnik językowy dla każdego, red. J. Podracki, Warszawa 1991. 
Inną współczesną formą popularyzacji są coraz częstsze audycje telewizyjne, w których znani językoznawcy przedstawiają problematykę dotyczącą kształtowania się i rozwoju języka polskiego. To zasadnicze novum w upowszechnianiu wiedzy o polszczyźnie po 1989 roku. Podobnie jak w przypadku audycji radiowych, zasadniczo sprowadza się ona do zagadnień związanych z kulturą języka polskiego oraz poprawnością mówienia. W tym miejscu należy odnotować jeden z pierwszych i chyba najpopularniejszych programów pt. „Ojczyzna Polszczyzna”, którego pomysłodawcą był Jan Miodek. Językoznawca ten, obok Andrzeja Markowskiego, Zbigniewa Bralczyka i Katarzyny Mosiołek-Kłosińskiej, uchodzi za jednego z najbardziej znanych współczesnych popularyzatorów wiedzy o języku polskim ${ }^{18}$. Jeszcze przed audycjami telewizyjnymi z powodzeniem upowszechniał współczesną polszczyznę na łamach prasy, radia oraz w publikacjach o charakterze popularnym ${ }^{19}$. Pewnym zwieńczeniem tych inicjatyw jest autorski leksykon, zatytułowany Stownik ojczyzny polszczyzny ${ }^{20}$ oraz wydawany w kilku częściach Stownik polsko@ polski ${ }^{21}$, stanowiący pokłosie kolejnego programu telewizyjnego, który ukazuje się w telewizji od 2009 roku.

Jednym $\mathrm{z}$ najpopularniejszych $\mathrm{w}$ ostatnim czasie wideoblogów jest program z zakresu poradnictwa językowego pt. „Mówiąc inaczej”. Jego autorką jest absolwentka filologii polskiej na Uniwersytecie Warszawskim, osobowość internetowa i menedżerka Paulina Mikuła. Prowadzi działalność popularyzatorką z zakresu kultury języka polskiego oraz współczesnej normy języ-

\footnotetext{
W ostatnich latach ukazało się wiele publikacji popularyzatorskich z zakresu poradnictwa językowego, zob. m.in. K. Kłosińska, Słownik przysłów. Przysłownik, Poznań 2004; J. Bralczyk, Świat przez słowa, Warszawa 2009; K. Kłosińska, Co w mowie piszczy? Poznań 2013; J. Bralczyk, A. Markowski, J. Miodek, Wszystko zależy od przyimka, Warszawa 2014; Zapomniane slowa, pomysł i redakcja M. Budzińska, Wołowiec 2014; J. Bralczyk, 500 zdań polskich, Warszawa 2015; J. Bralczyk, A. Markowski, J. Miodek, Trzy po 33, Warszawa 2016; P. Mikuła, Mówiac inaczej, Kraków 2016; M. Rusinek, Pypcie na języku, Warszawa 2017; M. Rusinek, A. Załazińska, Jak się dogadać, czyli retoryka codzienna, Kraków 2018; M. Rusinek, Niedorajda, czyli co nam radza poradniki, Warszawa 2019; J. Bralczyk, Zwierzyniec, Warszawa 2019.

18 Zob. G. Dąbkowski, Bralczyk - Markowski - Miodek. O sposobach popularyzacji kultury języka w mediach, „Studia Medioznawcze” 2004, nr 4, s. 11-16.

19 Wprawdzie badacz ten zajmował się popularyzacją wiedzy o języku polskim jeszcze przed transformacja ustrojową, to większość jego prac została opublikowana po 1989 roku, zob. m.in. J. Miodek, Rzecz o języku. Szkice o wspótczesnej polszczyźnie, Wrocław 1983; idem, Odpowiednie dać rzeczy stowo. Szkice o współczesnej polszczyźnie, Warszawa 1993; idem, Przez lata ze Stowem Polskim, Wrocław 1991; idem, Miodek drąży skatę, Wrocław 1993.

$20 \quad$ J. Miodek, Stownik ojczyzny polszczyzny, Wrocław 2002.

21 J. Miodek, Stownik polsko@polski z Miodkiem. Rozmowy profesora Jana Miodka o języku polskim z telewidzami z kraju i ze świata, Wrocław 2010; idem, Stownik polsko@polski z Miodkiem. Rozmowy profesora Jana Miodka o języku polskim z telewidzami z kraju i ze świata, t. 2, Wrocław 2013; idem, Stownik polsko@polski z Miodkiem. Rozmowy profesora Jana Miodka o języku polskim z telewidzami z kraju i ze świata, t. 3, Wrocław 2016.
} 
kowej. Swoje refleksje językowe przedstawia w trakcie swobodnej rozmowy, nierzadko okraszonej szczyptą humoru oraz ironii, szczególną uwagę zwracając na praktyczny wymiar poprawności wypowiedzi. Blog, który miał swoją premierą w serwisie YouTube w 2013 roku, do dnia dzisiejszego cieszy się niesłabnącą popularnością. Zapewne dzięki temu autorka stawia sobie kolejne wyzwania. W roku 2016 P. Mikuła wydała książkę, której tytuł nawiązuje wprost do jej programów internetowych, jednak zawartość jedynie w części stanowi pokłosie tych audycji ${ }^{22}$.

Analizując współczesną popularyzację nauki o języku, można odnieść wrażenie, iż zasadniczo sprowadza się ona do kultury języka polskiego, sprawności i poprawności językowej, a zatem do językoznawstwa stricte normatywnego. Wydaje się, że powód jest jeden - w ten sposób lingwiści odpowiadają na zapotrzebowania społeczne. Zasadniczo jednak współczesna popularyzacja nastawiona jest na pragmatykę językową. Jedną z przyczyn tego zjawiska jest zarówno atrakcyjność tematu, doniosłość społeczna, jak i rozchwianie współczesnej normy językowej, która obecnie nie tylko niespecjalistom sprawia sporo problemów. Stosunkowo rzadko współcześni badacze poruszają kwestie związane z historią języka czy też z bardzo ciekawą dyscypliną, jaką jest etymologia. Wyjątkiem może być tutaj cykliczny współczesny program telewizyjny J. Miodka pt. „Polska z Miodkiem”, poświęcony genezie nazw miejscowych. W audycji tej znany polski językoznawca w bardzo przystępny sposób wyjaśnia zagadnienia związane z pochodzeniem nazw miejscowych. Wydaje się, że i w tym przypadku program jest odpowiedzą na potrzeby potencjalnego odbiorcy. Sprzyja temu bardzo ciekawa, zagadkowa, tajemnicza, nierzadko sensacyjna, a dla niespecjalisty praktycznie niedostępna problematyka z zakresu analizy etymologicznej nazewnictwa miejscowego.

Należy zauważyć, iż popularyzacją w tradycyjnej i nowszej przestrzeni medialnej zajmują się nie tylko zawodowi językoznawcy, ale również niespecjaliści ${ }^{23}$. W dzisiejszej dobie polityki naukowej sprzyja temu coraz powszechniejszy trend, według którego popularyzacja nauki uprawiana przez specjalistów (w tym przypadku językoznawców) jest nieopłacalna w przeliczeniu na dorobek punktowy i przyszłą karierę naukowca. Nowe prawo o szkolnictwie wyższym i nauce (tzw. Konstytucja dla Nauki) wspomina wprawdzie o potrzebie komercjalizacji wiedzy, ale ta ostatnia jednak coraz częściej sprowadza się do produktu marketingowego, określanego mianem tzw. współczynnika wpływu. Wielu zatem decydentów traktuje artykuły popularyzatorskie jako coś gorszego, samego zaś naukowca niejednokrotnie stygmatyzuje i zalicza

\footnotetext{
22 P. Mikuła, op. cit.

23 Zob. B. Walczak, Jak niespecjaliści pisza o językoznawstwie diachronicznym, „Roczniki Humanistyczne" 2013, t. 61, z. 6, s. 57-75.
} 
do gorszej grupy badaczy. Bardzo dobrze podsumowała to M. Fikus, która jako doświadczona popularyzatorka, usłyszała kiedyś, że „,nie po to ją kształcono, żeby teraz rozmieniała się na drobne $\mathrm{w}$ jakichś podejrzanych imprezach pseudonaukowych" ${ }^{24}$. W istocie więc popularyzacja nauki to działanie, za które trzeba wiele zapłacić, a które sprzedaje się tanio ${ }^{25}$.

Pomimo niezbyt sprzyjających okoliczności, wprowadzenia reformy szkolnictwa wyższego, która w naukach humanistycznych zakłada efekty komercjalizacyjne, niedające się przełożyć na konkretne liczby, można zaryzykować stwierdzenie, że w każdym większym ośrodku akademickim są jednak orędownicy popularyzowania nauki o języku polskim. Przykładów jest bardzo wiele. Poza odnotowanymi już wyżej działaniami wielu profesorów bądź też absolwentów studiów filologii polskiej, można m.in. odnotować działalność popularyzatorską nieżyjącego już Bogusława Krei z Uniwersytetu Gdańskiego, Władysława Makarskiego z Katolickiego Uniwersytetu Lubelskiego Jana Pawła II, Urszuli Sokólskiej z Uniwersytetu w Białymstoku, Haliny Karaś z Uniwersytetu Warszawskiego, Ewy Kołodziejek z Uniwersytetu Szczecińskiego, Rafała Zimnego z Uniwersytetu Kazimierza Wielkiego w Bydgoszczy, Zygmunta Gałeckiego z Towarzystwa Przyjaciół Ziemi Łosickiej, Aliny Naruszewicz-Duchlińskiej z Uniwersytetu Warmińsko-Mazurskiego w Olsztynie, Agnieszki Karolczuk z Uniwersytetu Kardynała Stefana Wyszyńskiego w Warszawie, Natalii Sosnowskiej z Uniwersytetu Przyrodniczo-Humanistycznego w Siedlcach czy też Wojciecha Włoskowicza z Pracowni Onomastyki Instytutu Języka Polskiego PAN w Krakowie. Ponadto wielu językoznawców występuje w roli ekspertów w różnych środkach masowego przekazu.

Gorącym orędownikiem popularyzowania wiedzy językoznawczej przez specjalistów, tj. badaczy nauki o języku, jest B. Walczak. Autor ten pokazuje niedostatek upowszechniania wiedzy językoznawczej oraz bardzo dużą dysproporcję w tym zakresie, jaka istnieje między językoznawstwem a historią, literaturoznawstwem, kulturoznawstwem i podobnymi dyscyplinami naukowymi w zasobie wiedzy przeciętnego wykształconego Polaka ${ }^{26}$. Wpływa to na poziom świadomości i kompetencji przeciętnego użytkownika języka, który nierzadko nie zna podstawowych kwestii związanych z rozwojem oraz funkcjonowaniem polszczyzny. Konsekwencją jest również to, iż bardzo często osoby niewyspecjalizowane $\mathrm{w}$ językoznawstwie próbują upowszechniać tę dyscyplinę naukową. Ich działalność, niepoparta odpowiednią wiedzą i meto-

\footnotetext{
$24 \quad$ M. Fikus, op. cit., s. 182.

25 Eadem, Popularyzacja nauki. Dla kogo, przez kogo, jaki i dlaczego?, „Pauza Akademicka” 2008, nr 12, s. 4.

26 B. Walczak, Jeszcze o społecznych zadaniach językoznawstwa, „Poznańskie Studia Językoznawcze. Poznań Linguistic Forum” 2016, t. 32, s. 17.
} 
dologią, nierzadko prowadzi do niewłaściwego popularyzowania, które przynosi złe skutki. Tak jest też m.in. z coraz powszechniej wydawanymi słowniczkami gwarowymi, wykorzystującymi specyfikę językową mieszkańców zamieszkujących określone terytorium ${ }^{27}$. Publikacje takie, wydawane oraz udostępniane przez niespecjalistów, zawierają bardzo dużo błędów merytorycznych, metodologicznych, w istocie przynosząc więcej szkody niż pożytku. Podobnie można rozpatrywać pewne witryny internetowe, których autorzy próbują analizować nazewnictwo miejscowe bądź osobowe, nie mając świadomości o istnieniu dziedziny językoznawczej, jaką jest onomastyka ${ }^{28}$.

\section{POPULARYZACJA NAUKI O JĘZYKU NA LUBELSZCZYŹNIE}

Na koniec warto odnotować wybrane działania popularyzatorskie w środowisku lubelskich językoznawców. Inicjatywy takie miały miejsce zarówno w czasach przed transformacją ustrojową, jak i po 1989 roku. Spośród wielu osób należy wymienić znanych i cenionych w przestrzeni naukowej profesorów: Michała Łesiowa oraz Jerzego Bartmińskiego. Obydwaj wielokrotnie występowali ze swoimi referatami w trakcie odczytów popularnonaukowych. Nigdy nie unikali kontaktów z dziennikarzami różnych mediów, występując $\mathrm{w}$ środkach masowego przekazu w roli eksperta, by z jednej strony popularyzować wiedzę o języku polskim, $\mathrm{z}$ drugiej zaś - służyć pomocą $\mathrm{w}$ rozwiązywaniu lingwistycznych dylematów. J. Bartmiński jako znawca językowego obrazu świata oraz języka folkloru brał też m.in. udział jako członek jury w dorocznie organizowanym Ogólnopolskim Festiwalu Kapel i Śpiewaków Ludowych w Kazimierzu nad Wisłą. Drugi z językoznawców - nieżyjący już Michał Łesiów - poza wieloma odczytami popularyzatorskimi wydał szereg publikacji, w których w przystępny sposób przedstawiał zagadnienia językowe. W jednym z wywiadów stwierdził nawet bardzo odważnie, że z perspektywy czasu to on nawet nie wie, czy ważniejsze jest jego akademickie pisanie, czy też popularnonaukowe próby ${ }^{29}$.

27 H. Pelcowa, Regionalne stowniki gwarowe $w$ dobie globalizacji, [w:] Dawne z nowym taczac. In memoriam Mariani Kucała, t. 1, red. J. Klimek-Grądzka, M. Nowak, Lublin 2016, s. 251-260, zob. recenzje Mariusza Kopra: Stowniczek nazw fizjograficznych gminy Wisznice, Wisznice 2006, ss. 38, „Roczniki Humanistyczne” 2007, t. 55, z. 6, s. 157-169; idem, O słowniku gwary szczebrzeskiej Tomasza Gaudnika, „Zamojski Kwartalnik Kulturalny” 2013, nr 3, s. $123-125$.

28 Por. P. Złotkowski, Świadomość użytkowników forów genealogicznych w zakresie nominacji antroponimicznej, „Prace Językoznawcze” 2016, t. 18, z. 3, s. 219-236.

29 D. Nowacka, M. Jastrzębski, M. Borciuch, Michała Łesiowa gawęda o życiu. Wywiad z prof. dr. hab. Michałem Łesiowem, [w:] Z lubelskich badań nad Stowiańszczyzna Wschodnia. Księga 
Działania mające na celu upowszechnianie wiedzy językoznawczej mają miejsce nie tylko w murach uniwersytetu, ale również w innych instytucjach. Spośród wielu inicjatyw mających na celu popularyzację polszczyzny w województwie lubelskim jedną z kluczowych i rozpoznawalnych w skali ogólnopolskiej jest odbywający się już od kilku lat w okresie wakacyjnym w Szczebrzeszynie cykliczny Festiwal Stolica Języka Polskiego. Jednym z jego zadań jest popularyzacja wiedzy o języku polskim, promocja języka ojczystego, promocja ludzi pióra oraz przedstawicieli świata nauki, artystów, dziennikarzy. Ponadto festiwal jest doskonałą okazją do spotkania się z pisarzami, poetami, aktorami, językoznawcami, muzykami. W trakcie spotkań, wieczorów autorskich istnieje możliwość zakupu ich książek oraz bezpośredniej rozmowy, wzajemnej wymiany doświadczeń w klimacie urokliwego Roztocza.

Z uwagi na okolicznościowy i wyjątkowy charakter „Teki Komisji Polsko-Ukraińskich Związków Kulturowych" autor niniejszego artykułu uznał za stosowne przedstawienie w gronie lubelskich językoznawców osobno gorącego orędownika popularyzowania nauki o języku, jak również Jubilata, któremu został poświęcony niniejszy tom - prof. dr. hab. Feliksa Czyżewskiego $^{30}$. Ten niestrudzony badacz językoznawstwa polskiego i slawistycznego niejednokrotnie występował ze swoimi odczytami popularyzatorskimi w ośrodkach kulturalnych czy oświatowych, w których dzielił się w przystępny sposób wiedzą naukową. To dzięki Jego zaangażowaniu uczelnia, której był niestrudzonym pracownikiem, podpisała liczne umowy patronackie ze szkołami z regionu lubelskiego. W ramach takiej współpracy pracownicy Instytutu Filologii Słowiańskiej UMCS pod bacznym okiem swojego nauczyciela akademickiego efektywnie popularyzowali wiedzę językową, uczestnicząc w warsztatach czy jako jurorzy w konkursach językowych ${ }^{31}$. Jeszcze innym wymiarem popularyzacji są działania naukowe i popularyzatorskie Profesora na rzecz lokalnych społeczności samorządowych. Bardzo dobrym przykładem w tym zakresie są konferencje naukowe w Wisznicach, Włodawie czy też organizowane już od kilkunastu lat doroczne sympozja polsko-ukraińskie w Woli Uhruskiej. Te ostatnie stanowią doskonałą okazję do podsumowania spotkań naukowców, samorządowców, przedstawicieli organizacji pozarzą-

dedykowana profesorowi Michałowi Łesiowowi, red. D. Nowacka, M. Borciuch, A. Nowacki, M. Jastrzębski, Lublin 2010, s. 42.

30 Fragment dotyczący dokonań popularyzatorskich prof. Feliksa Czyżewskiego jest zmodyfikowaną nieco wersją części sprawozdania, które ukazało się kilka lat temu w jednym z czasopism naukowych, zob. M. Koper, M. Olejnik, Sprawozdanie z sympozjum w Woli Uhruskiej. Nauka w stużbie narodu. Dziesięć sympozjów polsko-ukraińskich (Wola Uhruska, 27 maja 2017 r.), „Slavia Orientalis” 2018, nr 1, s. 192-193.

31 A. Dudek-Szumigaj, Stowo o Jubilacie - w aspekcie działalności naukowej i dydaktycznej, [w:] Język i kultura pogranicza. Profesorowi Feliksowi Czyżewskiemu w 45-lecie pracy naukowej i dydaktycznej, red. A. Dudek-Szumigaj, Warszawa 2019, s. 13-14. 
dowych, hierarchów religijnych etc. Idea zbliżenia środowiska naukowego ze społecznością lokalną, wyjścia z zagadnieniami stricte naukowymi oraz ich metodologicznymi problemami z zacisza gabinetu badacza do szerszej grupy społeczeństwa od wielu lat przyświecała myśli prof. Feliksa Czyżewskiego. Badacz ten w pewien sposób wyprzedził współczesne trendy, coraz częściej bowiem mówi się o potrzebie współpracy środowiska naukowego z jednostkami samorządu terytorialnego, placówkami oświatowymi, organizacjami samorządowymi itp. Dzisiaj częstokroć wynika to jednak z potrzeb tzw. komercjalizacji wiedzy, promocji uniwersytetu oraz kształtowania jego pozytywnego wizerunku $\mathrm{w}$ mniejszych środowiskach, a także $\mathrm{z}$ zachęcania młodzieży szkolnej do zdobywania wiedzy akademickiej i studiowania na konkretnej uczelni, będącej nierzadko konkurentem dla innej placówki wyższej. Niemałą rolę odgrywają tutaj współczesne znaki czasu, tj. postępujący niż demograficzny oraz zmiany w mentalności współczesnej młodzieży, coraz częściej ukierunkowanej na postawę „mieć” niż „być”. Wydaje się, że zaangażowanie prof. Feliksa Czyżewskiego w zakresie popularyzacji wiedzy naukowej w lokalnych wspólnotach komunikatywnych oraz współpracy opartej na obopólnych korzyściach wynika z innych pobudek niż wiele różnych postmodernistycznych, nierzadko dyskusyjnych prądów. Polemizować można np. z coraz częstszym traktowaniem nauki, szczególnie zaś humanistyki, jedynie w kategoriach produktu marketingowego. Wydaje się, iż w tym zakresie wiedza ta jest najmniej przeliczalna na dane dotyczące sfery ekonomicznej, podążanie zaś za tym trendem doprowadza do zdehumanizowania humanistyki. Popularyzowanie wiedzy naukowej (również językoznawczej), dzielenie się nią w różnych środowiskach, pokazywanie wyników badań w szerszym polu kultury powinno bowiem leżeć w gestii każdego naukowca. Doświadczenia akademickie mogą być też pomocne w rozwiązywaniu problemów i potrzeb lokalnego społeczeństwa. Jak słusznie bowiem zauważyła w jednym ze swoich wykładów prof. Jadwiga Puzynina, „naukowiec jest przede wszystkim człowiekiem, a jego główne zadanie to służyć - także swoją pracą naukową tym, do czego każdy człowiek jest powołany: tworzenia dobra wspólnego rozumianego jako cywilizacja ludzi dobrej woli" ${ }^{\prime 32}$. W duchu popularyzatorskim można też zinterpretować słowa prof. Stefana Sawickiego, który w trakcie swojego wystąpienia w 2009 roku zgłosił postulat, aby wyniki badań naukowych były ukazywane w szerszym polu kultury ${ }^{33}$.

\footnotetext{
32 Słowa te padły w trakcie wykładu okolicznościowego wygłoszonego przez prof. Jadwigę Puzyninę przed odebraniem przez tę wybitną językoznawczynię Nagrody im. Księdza Idziego Radziszewskiego Towarzystwa Naukowego KUL za wybitne osiągnięcia naukowe w duchu humanizmu chrześcijańskiego (Lublin, 19 maja 2008 r.).

33 Wypowiedź prof. Stefana Sawickiego na uroczystości nadania mu tytułu doktora honoris causa UKSW w Warszawie (Warszawa, 26 listopada 2009 r.).
} 
Profesor Feliks Czyżewski to, jak pisał wielokrotnie przywoływany w tym artykule B. Walczak, „badacz doświadczony, pracowity, a ponadto przekonany o społecznych funkcjach uczonego-humanisty, głęboko zaangażowany w tworzenie warunków współpracy naukowej polsko-ukraińskiej (też polsko-białoruskiej), a poprzez nią budowanie mostów nad niełatwymi do przezwyciężenia zaszłościami historycznymi” ${ }^{34}$.

\section{PODSUMOWANIE}

Popularyzację nauki o języku dawniej i dziś łączy wspólny przedmiot zainteresowań. Różnice dotyczą obecności lub braku pewnych aspektów problematyki językowej. Zalążków popularyzacji wiedzy o języku polskim należy szukać u genezy samego językoznawstwa naukowego. W początkowym etapie rozwoju nauki o języku dominowała jednak nieklasyczna popularyzacja, tj. w miarę przystępne ukazywanie problematyki językowej w publikacjach mających również walory ściśle naukowe. W wydawnictwach tego typu dominowały zagadnienia historyczno-językowe (głównie etymologiczno-onomastyczne), dialektologiczne, etykiety językowej, związków języka z kulturą narodu itp. $Z$ czasem zaczęły ukazywać się na rynku wydawniczym typowe książki popularne o wyraźnie sprofilowanym charakterze, adresowane do czytelnika niespecjalisty, niedysponującego odpowiednim warsztatem naukowym. Ich wzrost przypada na lata powojenne. Znaczne zmiany w zakresie popularyzowania nastąpiły po 1989 roku, kiedy autorów tego typu prac zaczęła interesować przede wszystkim problematyka związana ze sprawnością i poprawnością językową oraz kulturą języka. Wynikało to z potrzeb polskiego społeczeństwa, z jednej strony uwolnionego od PRL-owskiej nowomowy, z drugiej zaś dostrzegającego intuicyjnie wariantywność w zakresie współczesnej normy językowej. Ponadto w ostatnich latach znacznie zwiększyły się kanały komunikowania oraz związane $\mathrm{z}$ nimi metody upowszechniania nauki w prasie, radiu, telewizji oraz, szczególnie na szeroką skalę, w Internecie. Na uwagę zasługują również coraz częściej pojawiające się akcje promujące język polski w kraju i poza jego granicami (m.in. dyktanda różnego szczebla, konkursy oratorskie). Dzięki tym inicjatywom upowszechnianie wiedzy o polszczyźnie dawnej i dzisiejszej przybrało masowy charakter. Poza globalizacją oraz medialnym charakterem współczesną popularyzację wiedzy o języku polskim cechuje narracja oraz dialog z potencjalnym odbiorcą. Zróżnicowane kanały komunikacji umożliwiają też indywidualny kontakt specjalisty z zainteresowanym kwestiami językowymi. Znacznie gorzej rysuje się

34 Z.W. Frączek, Jubileusz naukowy Profesora Feliksa Czyżewskiego, Lublin-Wisznice 2017, s. 15. 
popularyzowanie wiedzy językoznawczej uprawianej przez niespecjalistów, którzy nie dysponując odpowiednim warsztatem naukowym, popełniają wiele błędów oraz nie dostrzegają nasuwających się wątpliwości w zakresie zebranego i opisanego przez nich materiału. $Z$ uwagi na szeroki wachlarz zagadnień językowych oraz ich specyficzny charakter z jednej strony współcześnie dostrzega się niedostatek działań mających na celu popularyzację polszczyzny, z drugiej zaś zaleca, aby inicjatywy tego typu były podejmowane bądź przez samych językoznawców, bądź przynajmniej po konsultacji z przedstawicielami tej dyscypliny naukowej.

\section{BIBLIOGRAFIA}

Bralczyk Jerzy. 2009. Świat przez słowa. Warszawa: Wydawnictwo Naukowe PWN.

Bralczyk Jerzy. 2015. 500 zdań polskich. Warszawa: Agora.

Bralczyk Jerzy. 2019. Zwierzyniec. Warszawa: Agora.

Bralczyk Jerzy, Markowski Andrzej, Miodek Jan. 2014. Wszystko zależy od przyimka. Warszawa: Agora.

Bralczyk Jerzy, Markowski Andrzej, Miodek Jan. 2016. Trzy po 33. Warszawa: Agora.

Cienkowski Witold. 1967. Kalejdoskop językowy. Warszawa: Nasza Księgarnia.

Cienkowski Witold. 1980. Język dla wszystkich. Warszawa: Książka i Wiedza.

Cienkowski Witold. 1992. Tajemnice imion własnych. Kraków: Wydawnictwo Szkolne i Pedagogiczne.

Dąbkowski Grzegorz. 2004. Bralczyk - Markowski-Miodek. O sposobach popularyzacji kultury języka w mediach. „Studia Medioznawcze” nr 4: 11-16.

Dudek-Szumigaj Agnieszka. 2019. Stowo o Jubilacie - w aspekcie działalności naukowej i dydaktycznej. W: Język i kultura pogranicza. Profesorowi Feliksowi Czyżewskiemu w 45-lecie pracy naukowej i dydaktycznej. Red. Dudek-Szumigaj A. Warszawa: Stowarzyszenie Współpracy Polska-Wschód: 11-16.

Fikus Magdalena. 2008. Popularyzacja nauki. Dla kogo, przez kogo, jaki i dlaczego? „Pauza Akademicka” nr 12: 1, 4.

Fikus Magdalena. 2016. O upowszechnianiu nauki w Polsce na progu 2016. „Nauka” 1: 181-193.

Frączek Zbigniew Włodzimierz. 2017. Jubileusz naukowy Profesora Feliksa Czyżewskiego. Lublin-Wisznice: Polihymnia Sp. z o.o.

Grzelka Monika, Kula Agnieszka. 2012. Media publiczne w Polsce a popularyzacja wiedzy o języku polskim. „Poznańskie Studia Polonistyczne. Seria Językoznawcza” t. 19 z. 2: 9-19.

Jarosz Katarzyna. 2011. Komercjalizacja nauki i mechanizmy podnoszenia atrakcyjności artykutów popularnonaukowych. „Zeszyty Prasoznawcze” t. $54 \mathrm{nr}$ 3-4: 71-81.

Kłosińska Katarzyna. 2004. Słownik przysłów. Przysłownik. Poznań: Wydawnictwo Publicat.

Kłosińska Katarzyna. 2013. Co w mowie piszczy? Poznań: Wydawnictwo Publicat.

Koper Mariusz. 2007. Słowniczek nazw fizjograficznych gminy Wisznice, Wisznice 2006 ss. 38. „Roczniki Humanistyczne” t. 55 z. 6: 157-169 (recenzja).

Koper Mariusz. 2013. O słowniku gwary szczebrzeskiej Tomasza Gaudnika. „Zamojski Kwartalnik Kulturalny" nr 3: 123-125 (recenzja). 
Koper Mariusz, Olejnik Marek. 2018. Sprawozdanie z sympozjum w Woli Uhruskiej. Nauka w stużbie narodu. Dziesięć sympozjów polsko-ukraińskich (Wola Uhruska, 27 maja 2017 r.). „Slavia Orientalis” nr 1: 189-193.

Kucała Marian. 1992. Twoja mowa cię zdradza: regionalizmy i dialektyzmy języka polskiego. Kraków: Towarzystwo Miłośników Języka Polskiego.

Malec Maria. 1996. O imionach i nazwiskach w Polsce. Tradycja i współczesność. Kraków: Towarzystwo Miłośników Języka Polskiego.

Malec Maria. 2002. Słownik etymologiczny nazw geograficznych Polski. Warszawa: Wydawnictwo Naukowe PWN.

Mikuła Paulina. 2016. Mówiąc inaczej. Kraków: Flow Books.

Miodek Jan. 1983. Rzecz o języku. Szkice o współczesnej polszczyźnie. Wrocław: Ossolineum.

Miodek Jan. 1993. Odpowiednie dać rzeczy słowo. Szkice o współczesnej polszczyźnie. Warszawa: Państwowy Instytut Wydawniczy.

Miodek Jan. 1991. Przez lata ze Stowem Polskim. Wrocław: Ossolineum.

Miodek Jan. 1993. Miodek drąży skatę. Wrocław 1993: Towarzystwo Przyjaciół Polonistyki Wrocławskiej.

Miodek Jan. 2002. Słownik ojczyzny polszczyzny. Wrocław: Europa.

Miodek Jan. 2010. Stownik polsko@polski z Miodkiem. Rozmowy profesora Jana Miodka o języku polskim z telewidzami z kraju i ze świata. Wrocław: MARINA.

Miodek Jan. 2013. Stownik polsko@polski z Miodkiem. Rozmowy profesora Jana Miodka o języku polskim z telewidzami z kraju i ze świata t. 2. Wrocław: MARINA.

Miodek Jan. 2016. Stownik polsko@polski z Miodkiem. Rozmowy profesora Jana Miodka o języku polskim z telewidzami z kraju i ze świata t. 3. Wrocław: MARINA.

Nowacka Dagmara, Jastrzębski Mateusz, Borciuch Maria. 2010. Michała Łesiowa gawęda o życiu. Wywiad z prof. dr. hab. Michałem Łesiowem. W: Z lubelskich badań nad Stowiańszczyzna Wschodnia. Księga dedykowana profesorowi Michałowi Łesiowowi. Red. Nowacka D., Borciuch M., Nowacki A., Jastrzębski M. Lublin: Wydawnictwo KUL: $25-42$.

Ożóg Kazimierz. 2011. Polszczyzna przełomu XX i XXI wieku. Wybrane zagadnienia. Rzeszów: Stowarzyszenie Literacko-Artystyczne „Fraza”.

Pawelec Radosław. 2017. Popularyzacja, upowszechnianie, czynienie wiadomym wszem wobec. „Studia Medioznawcze” nr 3: 13-19.

Pelcowa Halina. 2016. Regionalne stowniki gwarowe $w$ dobie globalizacji. W: Dawne $z$ nowym łaczac. In memoriam Mariani Kucała. Red. Klimek-Grądzka J., Nowak M. t. 1. Lublin: Towarzystwo Naukowe KUL: 251-260.

Podracki Jerzy. 1991. Polszczyzna płata nam figle. Poradnik językowy dla każdego. Red. Podracki J. Warszawa: Wydawnictwo Radia i Telewizji.

Reczek Stefan. 1988. W rzecz polska wstapić. Wrocław: Ossolineum.

Reczek Stefan. 1988. Słowo się rzekło, czyli monolog o kulturze języka. Warszawa: Krajowa Agencja Wydawnicza.

Rospond Stanisław. 1976. Mówia nazwy. Warszawa: Wydawnictwo Szkolne i Pedagogiczne.

Rusinek Michał. 2017. Pypcie na języku. Warszawa: Agora.

Rusinek Michał. Załazińska Aneta. 2018. Jak się dogadać, czyli retoryka codzienna. Kraków: Społeczny Instytut Wydawniczy Znak.

Rusinek Michał. 2019. Niedorajda, czyli co nam radza poradniki. Warszawa: Agora.

Sieradzki Andrzej. 2003. Znaczenie imion. Warszawa: Klub dla Ciebie.

Walczak Bogdan. 2013. Popularyzacja wiedzy językoznawczej dawniej i dziś. Referat wygłoszony na jubileuszowej konferencji Instytutu Języka Polskiego PAN, zatytułowa- 
nej „Przyszłość językoznawstwa - językoznawstwo przyszłości” (Przegorzały, 1112 czerwca 2013 roku).

Walczak Bogdan. 2013. Jak niespecjaliści pisza o językoznawstwie diachronicznym. „Roczniki Humanistyczne t. 61, z. 6: 57-75.

Walczak Bogdan. 2016. Jeszcze o społecznych zadaniach językoznawstwa. „Poznańskie Studia Językoznawcze. Poznań Linguistic Forum" t. 32: 11-20.

Wierzbicka Anna. 1967. O języku dla wszystkich. Warszawa: Wiedza Powszechna.

Włoskowicz Wojciech. 2019. Nowomowa pseudometanaukowa? O języku polskiej polityki naukowej. „Poradnik Językowy” nr 10: 35-47.

Zapomniane słowa. Pomysł i redakcja M. Budzińska. Wołowiec 2014.

Złotkowski Piotr. 2016. Świadomość użytkowników forów genealogicznych w zakresie nominacji antroponimicznej. „Prace Językoznawcze” t. 18 z. 3: 219-236.

\section{ADDITIONAL REMARKS ABOUT POPULARIZING LINGUISTIC SCIENCE IN THE PAST AND TODAY}

Summary. The author presents the most important issues concerning popularization of linguistic science. Apart from defining the term popularization, the author lists the basic determinants of effective popularization. He discusses the history and the present day of activities in popularizing the science of the Polish language. Moreover, the author elaborates upon the state-of-the-art methods of contemporary science popularization, such as those relying on the vast richness of the media universe. In the final part of the article, the author outlines the popularization achievements of Professor Feliks Czyżewski.

Key words: popularization, Polish language, science, linguistics, linguist, knowledge, non-specialist, language culture

\section{ДО ПИТАННЯ ПОПУЛЯРИЗАЦІЇ НАУКИ ПРО МОВУ КОЛИСЬ І СЬОГОДНІ}

Анотація. У статті автор розглядає найважливіші питання, які стосуються популяризації науки про мову. Крім визначення терміна популяризація, називає головні детермінанти цього процесу, обговорює історію та сучасність популяризації науки про польську мову. Автор характеризує також новітні форми пропагування науки з урахуванням різноманітності світу засобів масової інформації. В останній частині статті в загальних рисах представлено популяризаторські досягнення проф. д-ра габ. Фелікса Чижевського.

Ключові слова: популяризація, польська мова, наука, мовознавство, мовознавець, знання, нефахівець, культура мови 
